\title{
Was the Joke on the Democrats Again? \\ Turnout and Partisan Choice in the 2004 U.S. Election
}

\author{
Michael Martinez and David Hill
}

The peak turnout rate in the 2004 presidential election highlights an important question for students of electoral participation: Did the higher levels of turnout advantage one of the two major party candidates? In this paper, we analyze state and county-level presidential and gubernatorial election results in 2000 and 2004, and find that Bush won the presidential election in spite of, rather than because of, the increase in turnout. The partisan effects of turnout varied across gubernatorial elections, and we found no evidence that local partisan minorities benefited from higher levels of turnout.

The 2004 presidential election was a closely, and at times bitterly, fought contest. Set against the backdrops of an extraordinary controversial presidential election four years earlier, so-called culture wars at home (manifest by eleven statewide referenda on gay marriage; see Donovan et al. 2005), a divisive real war abroad, and acrimony about the military records (or lack of them) of the presidential candidates, the two major parties and their allied interest groups waged extensive and intense drives to register as many new voters as possible (Economist 2004), and spending more money than ever before on a presidential election (www.opensecrets.org). Both parties' intense mobilization efforts drove millions of voters to the polls, and millions more were drawn by the perception that Bush and Kerry offered more of a choice than an echo and, following the closest of margins in the 2000 presidential election, a belief that every vote matters (Bergan et al. 2005). A record number of voters $(123,675,639)$ cast ballots on Election Day in 2004, translating into the highest turnout rate since the adoption of the Twenty-sixth Amendment (see Figure 1). Compared to the 2000 presidential election, turnout was up four points (as a percent of the voting age population) or five points (as a percent of the voting eligible population).

\footnotetext{
An earlier version of this paper was presented at the Annual Meetings of the American Political Science Association, Washington, DC, September 1-4, 2005. We appreciate research assistance provided by MacKenzie Moritz.

MICHAEL MARTINEZ is an associate professor of political science at the University of Florida. DAVID HILL is an associate professor of political science at Stetson University.
}

The American Review of Politics, Vol. 28, Summer, 2007: 81-95

(c)2007 The American Review of Politics 
Figure 1. Turnout in Presidential Elections

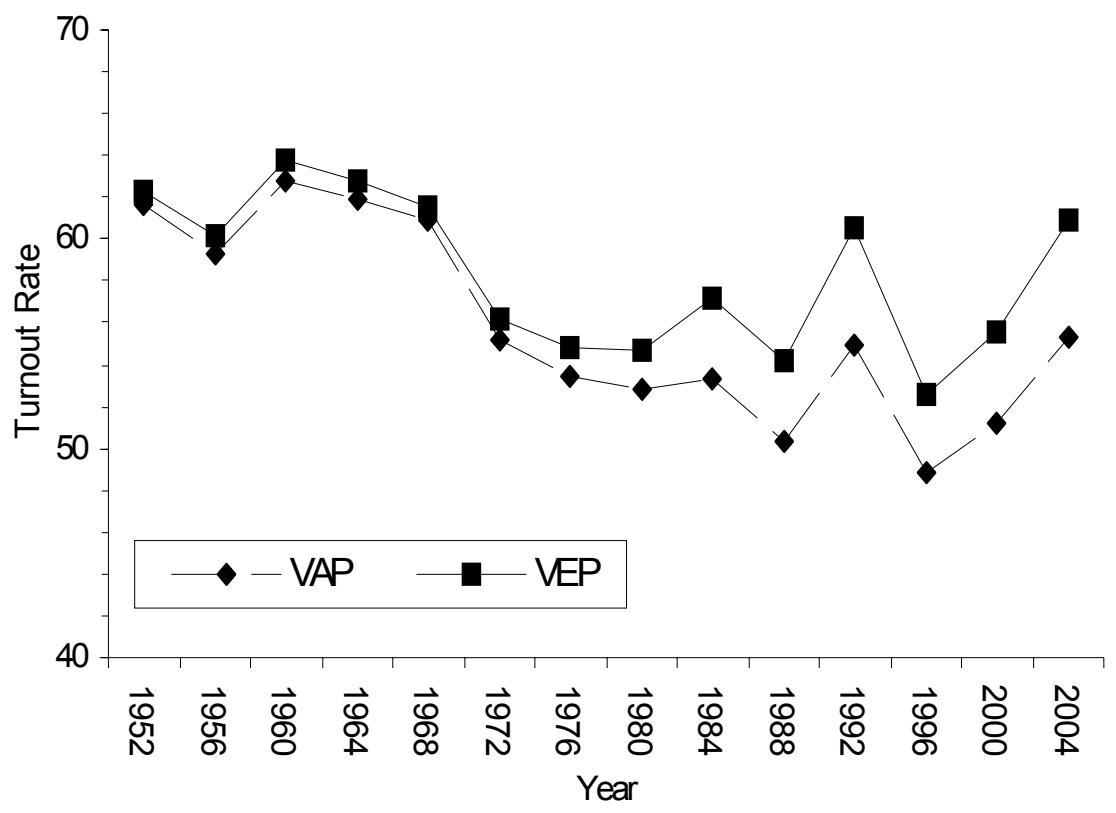

The peak turnout rate in 2004 highlights an important question for students of electoral participation: Did the higher levels of turnout advantage one of the two major party candidates? While most pundits seem to relentlessly cling to and propagate the conventional wisdom that higher turnout should help the Democrats, early scholarly analyses of the 2004 election suggested that the dramatic increase in turnout from 2000 and the slight increase in Bush's margin of victory may have been more than coincidental. However, in this article, our analysis of state and county level data from 2000 and 2004 will show that Bush defeated Kerry in spite of, rather than because of, the historic increase in turnout. We will also show that any benefit from turnout that Kerry might have enjoyed did not always extend further down the ballot to Democratic gubernatorial candidates.

\section{Partisan Consequences of Turnout}

Since non-voters, as a group, tend to be relatively poorer and less educated than voters, as a group, the conventional reasoning suggests that bringing more of the former into the active electorate should tilt the electoral scales toward the left in most cases. After all, a smaller electorate would include relatively more educated and wealthy people who would see the 
virtues of a laissez-faire economy, while a larger electorate would include more working-class people of modest means who can foresee (or see) the attractions of social safety nets. To the degree that both groups vote according to their own class interests, this model suggests that Republicans should pray for rain on every Tuesday following the first Monday in evennumbered years.

Although there is some support for the conventional wisdom in the scholarly literature (Radcliff 1994; Tucker and Vedlitz 1986), more recent analyses have found that the partisan effects of higher turnout are either highly variable or situationally contingent (Citrin, Schickler, and Sides 2003; Erikson 1995; Nagel and McNulty 1996; Nagel and McNulty 2000), or are very weak, having declined considerably over the last four decades (Martinez and Gill 2005). These results suggest that the underlying assumptions of class-voting in the conventional model could be absent, due to the increasing salience of moralist issues that cut across class cleavages. As cross-cutting issues such as abortion (Abramowitz 1995) and gay rights (Haider-Markel 1999) become more important in framing voters' ballot choices, any class related advantages for Democrats from higher turnout might be expected to dissipate.

Early scholarly analyses of the 2004 U.S. presidential election have even turned the conventional wisdom on its head, suggesting that higher turnout worked to the advantage of the incumbent Republican president and played a small role in his victory. For example, Campbell (2005) observes that turnout rates were higher in states that were very close $(\mathrm{McD}$ Donald 2004) and in states where Bush received a larger share of the vote. This finding accords with Burden (2004), who also finds a positive effect of state level turnout change on Bush's vote share in 2004, controlling for battleground state status, the presence of Nader on the presidential ballot, and the presence of an anti-gay marriage referendum.

While these analyses are helpful in underscoring the pivotal role of the battleground states in the 2004 election, we think that an alternative specification might help us to better pinpoint the partisan effects of turnout. In particular, we believe that county level data will provide us with better estimates of the effects of turnout on partisan choice, both because county level data are lower levels of aggregation of individual behaviors, and because counties reflect salient local political contexts.

Thus, for example, county level data will permit us to test DeNardo's (1980) prediction that the partisan advantage of higher turnout might be expected to accrue to the minority party within any given area, since higher stimulus elections would mobilize more weak and leaning partisans with a greater propensity to defect. This defection-model would predict that higher turnout should advantage Democrats most in "red" counties, ${ }^{2}$ where 
peripheral Republicans (with a propensity to defect to Democratic candidates) outnumber peripheral Democrats (with a propensity to defect to Republican candidates). In "blue" counties, on the other hand, the greater number of peripheral Democrats (with a propensity to defect to the Republican candidates) should work to the advantage of Republican candidates. Empirical support for this model has been mixed as well. While the predictions fit some cross-sectional analyses of state results well (Nagel and McNulty 1996; Nagel and McNulty 2000), Martinez and Gill (2005) found no evidence that higher turnout would have helped the Republicans in 1964, when the Democratic majority was at its peak.

Thus, our central questions are:

1. Did the increase in turnout work to the advantage of either party in the 2004 U.S. election? And,

2. Were the partisan consequences of turnout variable across locales?

\section{Data}

Most of our state and county level turnout and electoral data for the 2000 and 2004 presidential elections from Leip's (2005) compilation of publicly available data, and we confirmed the validity of Leip's reports of voting age population (VAP), the number of votes cast for President, and votes cast for particular candidates through spot checks with several states' division of elections and the U.S. Census Bureau websites. Though we generally prefer to calculate turnout as votes cast as a proportion of the voting eligible population (McDonald and Popkin 2001; McDonald 2003), we are presently unaware of any calculations of the voter eligible population at the county level. ${ }^{3} \mathrm{We}$ also gathered county-level gubernatorial election data for 2000 and 2004 from the official Secretary of State or Division of Elections website for each of the eleven states that held gubernatorial elections in those years (see Appendix).

\section{Methods}

We estimate how much increases in the Republican vote at the state level are attributable to increases in turnout from the following equation:

$$
\frac{\text { GOPVotes }_{2004}}{\text { VotesCast }_{2004}}=\alpha+\beta_{1} \frac{\text { GOPVotes }_{2000}}{\text { VotesCast }_{2000}}+\beta_{2}\left(\frac{\text { VotesCast }_{2004}}{\text { VEP }_{2004}}-\frac{\text { VotesCast }_{2000}}{V E P_{2000}}\right)+e
$$

A positive $\beta_{2}$ coefficient would indicate that, on average, Bush benefited from higher turnout, and a negative $\beta_{2}$ coefficient would indicate that the Democrats benefited from higher turnout. At the county level, where data on the Voter Eligible Population (VEP) are not available, we estimate 
$\frac{\text { GOPVotes }_{2004}}{\text { VotesCast }_{2004}}=\alpha+\beta_{1} \frac{\text { GOPVotes }_{2000}}{\text { VotesCast }_{2000}}+\beta_{2}\left(\frac{\text { VotesCast }_{2004}}{\text { VAP }_{2004}}-\frac{\text { VotesCast }_{2000}}{\text { VAP }_{2000}}\right)+e$

\section{Did Increased Turnout Help Bush?}

We begin our answer to the "higher turnout-so what?" question by examining a simple scatterplot of the change in the percent of the vote that Bush received between 2000 and 2004 by the change in the VEP turnout rate by state. Figure 2 shows that states' rates of turnout change varied a great deal, but it is noteworthy that turnout increased in every one of the fifty states and the District of Columbia. Some had sharp increases: the battleground states of Florida, Ohio, Colorado, and Nevada all had increases greater than 9 percent. In contrast, three "deep blue" states (Connecticut, New York, and Vermont) and three "deep red" states (Alaska, Montana, and Wyoming) each had increases of less than 3 percent. Overall, we see a weak negative relationship between the change in voter turnout and the change in the Bush vote. Bush carried the seven states that had the largest turnout increases (Ohio, Nevada, Florida, South Dakota, Colorado, Georgia, and Arizona), but it appears that on the whole, higher turnout tended to work in Kerry's favor. Although there are large residuals above and below the regression line, on average, Bush improved most in states where turnout increased least.

Figure 2. Partisan Effects of Turnout

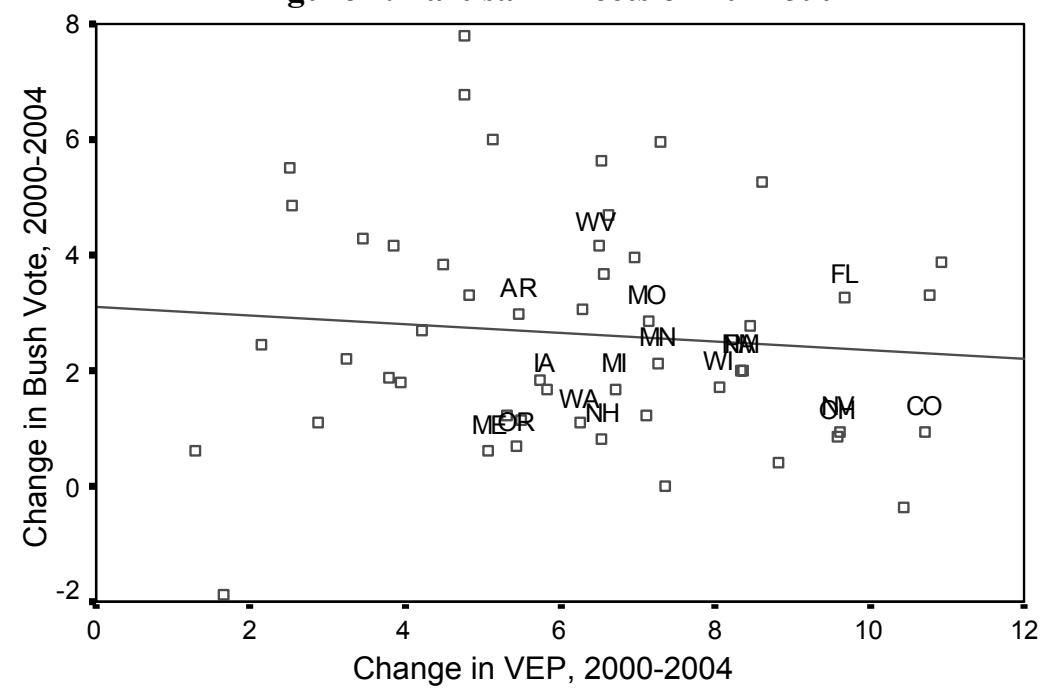


Table 1. Effects of Turnout Changes on Bush Vote

\begin{tabular}{lccc}
\hline \multicolumn{1}{c}{ B } & Std Err & Sig. \\
\hline States & 5.635 & 1.373 & 0.000 \\
(Constant) & 0.952 & 0.029 & 0.000 \\
Bush Vote 2000 & -0.092 & 0.094 & 0.333 \\
$\Delta$ VEP Turnout (2000 to 2004) & 51 & \\
Number of Cases & 0.98 & \\
$\mathrm{R}^{2}$ & & \\
WLS estimates (weighted by voting eligible population 2000) & \\
----------------------------------------- & \\
Counties & & & \\
(Constant) & 3.620 & 0.195 & 0.000 \\
Bush Vote 2000 & 1.014 & 0.004 & \\
$\Delta$ VAP Turnout (2000 to 2004) & -0.296 & 0.016 \\
Number of Cases & 3109 & \\
$\mathrm{R}^{2}$ & 0.96 & \\
WLS estimates (weighted by voting age population 2000) & \\
\end{tabular}

Table 1 shows the Weighted Least Squares estimates of the effects of turnout change on the Bush vote in 2004, controlling for the Bush vote in 2000. In both the state level equation and the county level equation, the regression coefficient on the lagged Bush vote is very close to 1.0 , reinforcing the notion that the electoral contours of the 2000 and 2004 presidential elections were very similar. Moreover, this means that the positive intercept can be interpreted as the average (weighted) swing toward Bush, controlling for changes in turnout. In other words, our state model suggests that if turnout in 2004 had remained at its 2000 level, the average swing to Bush would have been slightly higher than was actually the case. Our estimate of the state level equation suggests that a one percent increase in turnout (as a percent of VEP) is associated with a mild ( 0.09 percent) decrease in aggregate support for Bush, controlling for the overall Republican swing. In our view, this aggregate analysis of the 2004 election tracks with recent individual level analyses of other elections that show a modest pro-Democratic effect of higher turnout, though the estimated effect is slightly greater than individual level estimates based on the 2000 election. Controlling for the actual partisan swing in the 2004 election and with the heroic assumption of linear effects, Kerry would have needed a turnout rate of over 74 percent of 
the voting eligible population (as opposed to the actual turnout rate of $61 \%$ ) to overcome Bush's partisan advantage among actual voters.

That punchline is even stronger in the estimate of the county level equation (shown in the lower panel of Table 1) where a one percent increase in turnout (as a percent of VAP) is associated with a 0.30 percent decrease in support for Bush, again controlling for the significant Republican swing. That said, it appears that Bush won his second term in spite of, rather than because of, the increase in turnout.

\section{Gubernatorial Elections}

Our county-level data also provide an insight into partisan effects of turnout in the eleven gubernatorial elections held in 2004. In the regression model shown in Table 2, the dependent variable is the change in the Republican gubernatorial candidate's share of the vote in each county between 2000 and 2004, with positive numbers indicating that the Republican candidate received a larger share of the vote in 2004. The main independent variables of interest are the interactions between the state dummy variables and the change in turnout, with fixed effects for each state (suppressing the overall intercept). A positive regression coefficient on a state turnout interaction tells us that the higher turnout in 2004 was associated with an increase in support for the Republican gubernatorial candidate (controlling for the partisan swing in the gubernatorial election), while a negative effect indicates support for the conventional model's prediction that increased turnout would boost Democratic support.

Turnout effects vary across these eleven states. In Delaware and West Virginia, increases in turnout were associated with greater support for the Republican gubernatorial candidate, while in Missouri, Washington, and North Carolina, turnout increases were associated with greater support for the Democratic candidates. Indiana and Montana are especially notable for the flat turnout slopes: Republican candidates for governor neither benefited nor suffered in counties with the most significant increases in turnout in 2004. The highly variable results at the gubernatorial level show that, while increases in interest in the election may have mobilized more Kerry supporters than Bush supporters, the pro-Democratic effects of higher turnout did not always trickle down the ballot. The scatterplot of the slopes in Table 2 and the percent of votes that Bush received in 2000 (shown in Figure 3) suggests a slight tendency for increased turnout to favor Republican gubernatorial candidates in the most Democratic states $(b=-.02, r=-.26)$, though our sample is small (eleven states) and there are large residuals on both sides of the regression line (see also Nagel and McNulty 1996, 790). 
Table 2. Effects of Changes in Turnout on Changes on Vote for Republican Governor Candidates, 2000-2004

\begin{tabular}{|c|c|c|c|}
\hline & \multicolumn{3}{|c|}{ Counties } \\
\hline & $\mathrm{B}$ & Std Err & Sig. \\
\hline Delaware & 6.747 & 2.592 & 0.009 \\
\hline Indiana & -40.319 & 1.157 & 0.000 \\
\hline Missouri & 8.437 & 1.602 & 0.000 \\
\hline Montana & -4.862 & 1.465 & 0.001 \\
\hline North Carolina & -0.765 & 0.991 & 0.441 \\
\hline New Hampshire & 11.737 & 7.510 & 0.119 \\
\hline North Dakota & 16.938 & 1.915 & 0.000 \\
\hline Utah & 2.817 & 3.451 & 0.415 \\
\hline Vermont & 19.272 & 1.894 & 0.000 \\
\hline Washington & 11.608 & 1.056 & 0.000 \\
\hline West Virginia & -19.956 & 2.478 & 0.000 \\
\hline$\Delta$ Turnout Delaware & 1.222 & 0.149 & 0.000 \\
\hline$\Delta$ Turnout Indiana & 0.014 & 0.236 & 0.951 \\
\hline$\Delta$ Turnout Missouri & -0.895 & 0.206 & 0.000 \\
\hline$\Delta$ Turnout Montana & -0.124 & 0.518 & 0.812 \\
\hline$\Delta$ Turnout North Carolina & -0.390 & 0.154 & 0.012 \\
\hline$\Delta$ Turnout New Hampshire & -1.020 & 1.158 & 0.379 \\
\hline$\Delta$ Turnout North Dakota & -0.389 & 0.458 & 0.396 \\
\hline$\Delta$ Turnout Utah & -0.185 & 0.585 & 0.752 \\
\hline$\Delta$ Turnout Vermont & 0.493 & 0.699 & 0.481 \\
\hline$\Delta$ Turnout Washington & -0.689 & 0.268 & 0.010 \\
\hline$\Delta$ Turnout West Virginia & 1.029 & 0.388 & 0.008 \\
\hline Number of Cases & 567 & & \\
\hline $\mathrm{R}^{2}$ & 0.93 & & \\
\hline
\end{tabular}

\section{Does Turnout Help the Local Minority?}

The results in Figure 3 are weakly consistent with DeNardo's (1980) prediction that higher turnout should work to the benefit of the minority party within a political setting. DeNardo argued that the peripheral voters, those who abstain in lower stimulus elections but are enticed to the polls in high stimulus elections, also tend to be more likely to defect to the opposing party in any given race. Since heavily Democratic districts would tend to have more peripheral Democrats willing to defect to Republican candidates (and vice versa), DeNardo's hypothesis suggests that turnout increases would work to Republicans' benefit in the most Democratic areas, and to Democrats' benefit in the most Republican areas. 
Figure 3. Partisan Effects of Turnout in Gubernatorial Elections by Bush Vote in 2000

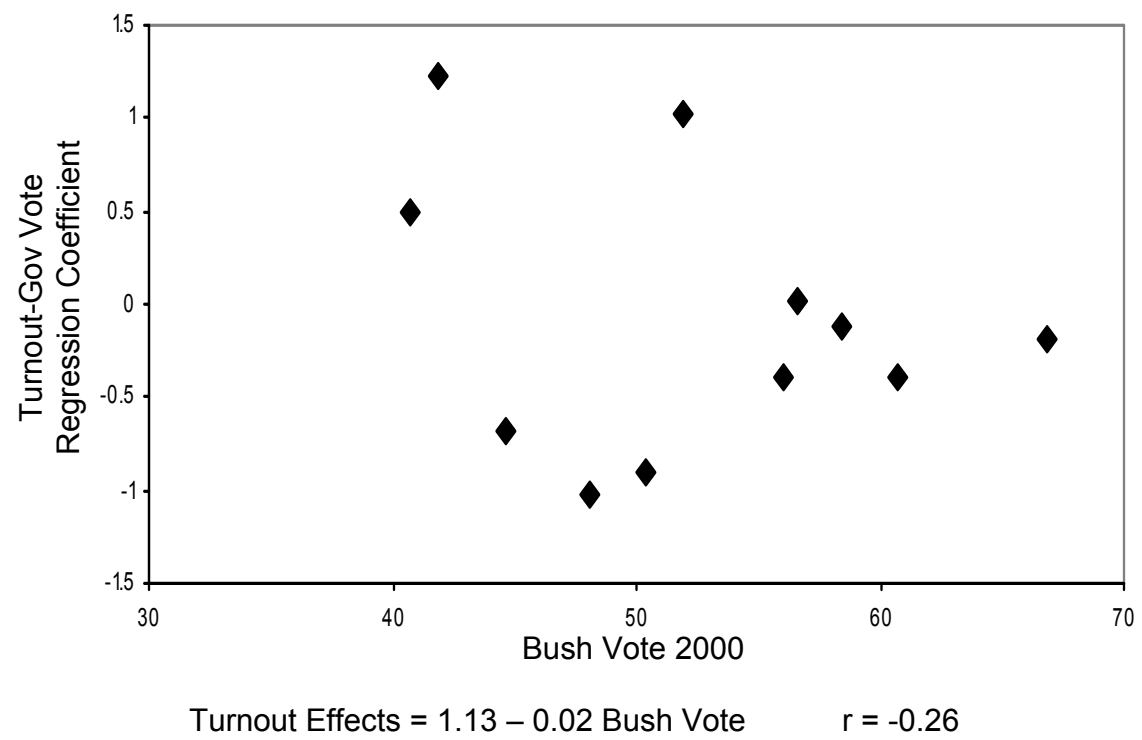

We turn back to the presidential race with our county level data for an additional test of this hypothesis. Table 3 shows two tests of this prediction. In the first test, we classified 2232 counties that Bush carried with at least 52 percent of the two-party vote in both 2000 and 2004 as "red," 288 counties where Bush had less than 48 percent of the two-party vote in both elections as "blue," and 684 others as "purple." Model 1 in Table 2 shows the estimation of the basic turnout-partisan outcome model, with interactions between turnout change and "red" / "blue" status. The negative main effect of turnout change (denoting the effect in the omitted "purple" counties) is proDemocratic: a one-percent increase in the turnout is associated with a .43 percent decrease in Bush's share of the vote. Turnout effects in Democratic counties were similar, as shown by the trivial coefficient on the "blue" interaction term. In Republican counties, the relationship between turnout-change and partisan outcomes was closer to flat (the sum of the main effect and the "red" interaction coefficient is only 0.13). Thus, increased turnout appears to have helped Kerry the most in competitive and Democratic counties, but much less so in Republican counties, contrary to the DeNardo prediction.

Of course, it is possible that the "tipping point" of turnout effects falls outside the range of 48 percent to 52 percent Bush support in 2000 that is implicit in our classification of counties. To account for that possibility, we provide another test of DeNardo's hypothesis in the Model 2 of Table 3, 
$90 \mid$ Michael Martinez and David Hill

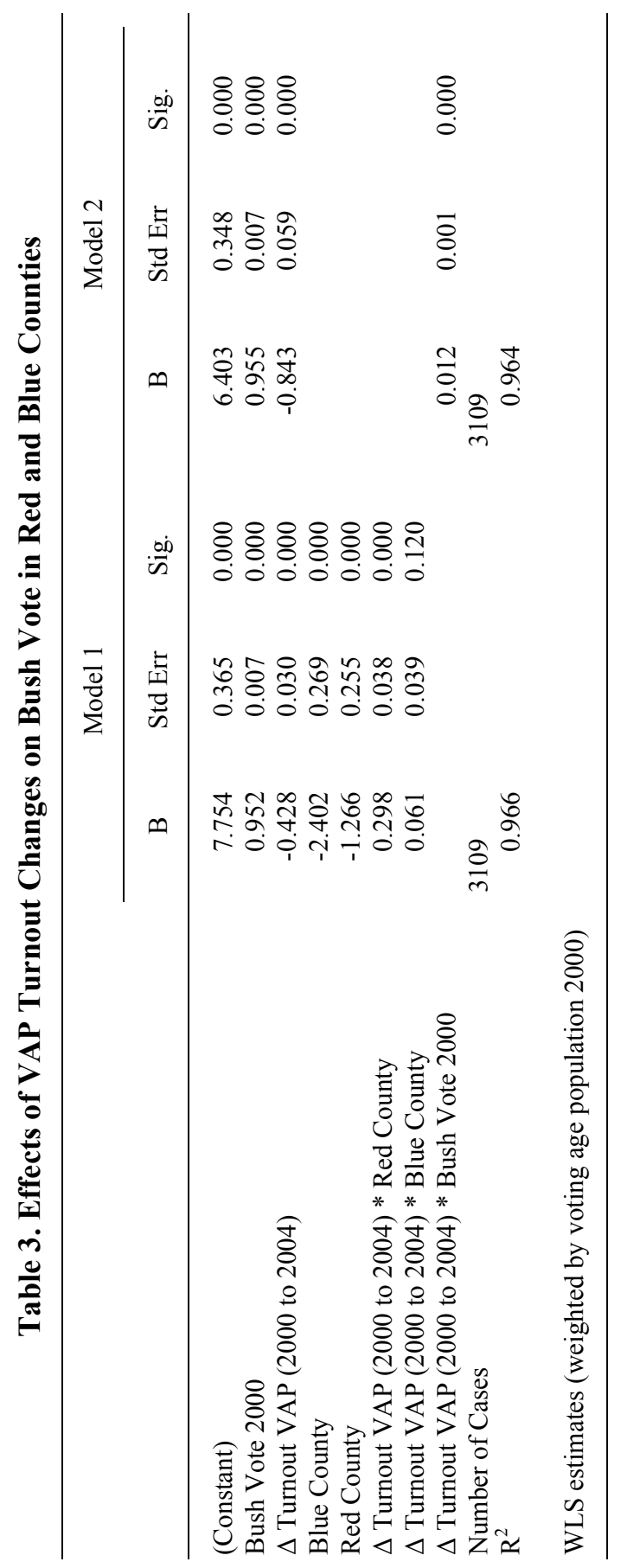


where we regress Bush vote in 2004 on Bush support in 2000, turnout change, and their interaction. The DeNardo hypothesis would predict a negative interaction coefficient, that is, any pro-Democratic effects of turnout should be stronger in counties with more potential Republican defectors. Again, our estimates provide no support for DeNardo's prediction, as the main effect of turnout change is negative (pro-Kerry), and the interaction term is positive and significant. We can show the estimated conditional effects of turnout change in this model by comparing prototypical "blue" and "red" counties. In a "blue" county where Bush received only 40 percent of the vote in the 2000 election, the total estimated effect of turnout change is equal to the main effect (-.843) plus the interaction effect (.012) multiplied by 40 , or a pro-Kerry -.363 . In a "red" county where Bush received 60 percent of the vote in 2000, the estimated effect of turnout change would be $-.843+(.012 * 60)$, or -.122 , faintly pro-Kerry but weak. Thus, while DeNardo was insightful about the role that defections play in limiting the partisan effects of turnout, we do not find support for his prediction that turnout should work to the advantage of local minorities (see also Tucker and Vedlitz 1986).

\section{Discussion}

In this paper we have addressed whether turnout increases in 2004 were associated with an advantage to either the Democratic or Republican candidates, and whether those effects varied by the local partisan context. We found that turnout increases were weakly associated with greater support for Kerry at the presidential level, in contrast to some earlier analyses that suggested that Bush benefited from the high turnout in 2004. But turnout effects on gubernatorial races were quite variable, suggesting that "peripheral" voters who are the last to accept the candidates' invitations to come to the polling booths may also be the most fickle. More of them appeared to support Kerry, but not all Democratic gubernatorial candidates benefited.

However, we again found little support for DeNardo's notion that higher turnout would benefit local minorities in the presidential election. Higher turnout helped Kerry in red, blue, and purple counties alike, though least in the red counties, where DeNardo had led us to expect to find more defecting Republican voters. The question, then, is why were weak partisan defections not evident in 2004? DeNardo assumes that in high-stimulus elections, weak partisans from both sides will encounter strong short-term forces that will motivate them to defect, but short-term forces can also reinforce party loyalties. In landslide elections, there are plenty of partisan defectors (Republicans who couldn't stomach Goldwater in 1964, and Reagan Democrats in 1984), but short-term forces kept weak Democrats in 
1964 and weak Republicans in 1984 loyal to their parties' standard bearers. In the close election we saw in 2004, the two candidates presented distinctly different visions on the key issues of the day, reinforcing weak and leaning partisans on both sides, and strengthening the partisan cleavage in the electorate, at least at the presidential level (Abramson et al. 2006, 198-201). This, combined with the competitiveness of the campaign, created a context in which the base of each party was relatively unified in its commitment to win. The campaigns, in turn, used these engaged and committed partisans to wage extensive and intense mobilization campaigns targeted toward the supporters of each candidate (Bergan et al. 2005). This environment of partisan supporters engaged by the perceived polarization of the candidates and the two parties specifically targeting partisan supporters reduced the likelihood that marginal partisans would defect in safe counties. ${ }^{4}$

While some increase in turnout from 2000 to 2004 is due to generalized increases in the perceptions that the outcome and one vote's individual contribution to the outcome both matter, a portion of the increase is due to changes in the behavior of the campaigns. ${ }^{5}$ Campaigns are, of course, desperate to mobilize targeted portions of the electorate, but who would sigh relief if forces of nature or politics suppressed turnout among the probable supporters of the opposition. Mobilization efforts by the campaigns are, of course, intended to have very biased partisan effects, but their success is constrained in part by counter-mobilization by the opposition, as well as any effects that stem from generalized increases in interest that precipitate from the mobilization of partisans.

\section{APPENDIX}

\section{Description of Variables (Predicted Direction)}

\section{Dependent Variable}

Party Identification

\section{Independent Variables}

Age (+)

Gender $(+)$

Southern Residence $(+)$
"Generally speaking, do you usually think of yourself as a Republican, a Democrat, an Independent, or what? Would you call yourself a strong Republican or a not very strong Republican? Would you call yourself a strong Democrat or a not very strong Democrat? Do you think of yourself as a closer to the Republican Party or the Democratic Party?" $1=$ Democrat, 0 otherwise.

Age in years, ranging from 17-90.

$1=$ female, $0=$ male.

$1=$ South. $0=$ Non-South. South = Alabama, Arkansas, Florida, Georgia, Kentucky, Louisiana, Mississippi, North Carolina, South Carolina, Tennessee, Texas, Virginia, and West Virginia. 


\section{APPENDIX (continued)}

Political Ideology $(+)$

Education (-)

Family Income (-)

Public Assistance (+)

Labor Union $(+)$

Black Issues Democrat (+)

Black Political Power $(+)$

Black-White Economics (-)
"Do you think of yourself as more like a liberal or more like a conservative?" $1=$ conservative, $2=$ neither, refuses to choose, $3=$ liberal.

$1=$ grade school (grades 1-8), 2 = some high school, no degree (grades 9-12), $3=$ high school degree, $4=$ some college, no degree, $5=$ Associate's/2-year degree, Bachelor's/4-year degree, 6 = some graduate school, Master's degree, doctorate/law degree.

Combined income of all members of your family living with respondent, for 1995 before taxes.

"Did you or anyone in your household receive any other income in 1995 from:" ADC or AFDC, food stamps, Social Security, Supplemental Security Income, unemployment compensation, or worker's compensation? $1=$ yes, $0=$ no.

"Do you or anyone else in this household belong to a labor union?" $1=$ yes, $0=$ no.

"How hard do you think the Democratic Party really works on issues Black people care about?" 1 = not hard at all, $2=$ not too hard, 3 = fairly hard, $4=$ very hard.

Black Issues Republican (-) "How hard do you think the Republican Party really works on issues Black people care about?" 1 = not hard at all, $2=$ not too hard, 3 = fairly hard, $4=$ very hard.

"Among the three, which strategy is best for increasing the political power of Blacks in the United States?"

$-1=$ support for the Republican Party, $0=$ Independent

Black Political Party, 1 = support for the Democratic Party.

"On the whole, would you say that the economic position of Blacks is better, about the same, or worse than whites?" $1=$ worse, $2=$ same, $3=$ better.

\footnotetext{
Sources of County Level Data on Gubernatorial Elections

Delaware

http://www.state.de.us/election/archive/elect04/2004_election_index.shtml

Indiana http://www.in.gov/sos/elections/elections/

Missouri http://www.sos.mo.gov/enrweb/

Montana

http://sos.state.mt.us/ELB/Results.asp

New Hampshire http://www.sos.nh.gov/election\%20information.htm

North Carolina

http://www.sboe.state.nc.us/

North Dakota http://web.apps.state.nd.us/sec/emspublic/gp/electionresultssearch.htm

Utah http://www.elections.utah.gov/electionresults.html

Vermont http://vermont-elections.org/elections1/2004_election_info.html
} 


\section{NOTES}

${ }^{1}$ McDonald and Popkin (2001) argue that turnout in the U.S. is artificially low because the voting age population (turnout=votes/voting age population) includes individuals who are not eligible to vote, such as legal and illegal aliens and institutionalized citizens. The authors re-estimate turnout using what they call the voting eligible population, which does not include ineligible persons and conclude that turnout in American elections is, on average, about four percentage points higher than the artificially depressed rate using the voting age population. Nonetheless, even with this new measure turnout in U.S. elections is still substantially lower than in almost all industrialized democracies. All of the data used in this paragraph are taken from Michael McDonald's website at http://elections.gmu.edu/voter turnout.htm.

${ }^{2}$ We agree with Fiorina (2005) that most states are probably more "pink" and "slate" than "red" and "blue," but we use the now conventional shorthands of "red" and "blue" to reflect recent partisan trends in the U.S. states.

${ }^{3} \mathrm{We}$ made two adjustments to the data that reflect changes in county jurisdictions between the 2000 and 2004 general elections. In 2001, Broomfield County (Colorado) was formed from parts of four adjacent counties (Adams, Boulder, Jefferson, and Weld). We treated those five counties are treated as one unit in both 2000 and 2004. In Virginia, Clifton Forge City was autonomous in 2000, but subsequently was folded back into Alleghany County. We treated Clifton Forge City as part of Alleghany County in both 2000 and 2004.

${ }^{4}$ At the individual level, partisan defections among both Democrats and Republicans were lower in 2004 than in 2000 (Abramson et al. 2006, 192-195).

${ }^{5}$ Bergan et al. (2005) found that about two-thirds of the increase in turnout in 2004 was due to heightened interest in the campaign within the electorate, while the remaining one- third could be attributed to the mobilization efforts of the campaigns.

\section{REFERENCES}

Abramowitz, Alan I. 1995. It's Abortion Stupid: Policy Voting in the 1992 Presidential Election. Journal of Politics 57(1):176-186.

Abramson, Paul R., John H. Aldrich, and David W. Rohde. 2006. Change and Continuity in the 2004 Elections. Washington, DC: CQ Press.

Bergan, Daniel E., Alan S. Gerber, Donald P. Green, and Costas Panagopoulos. 2005. Grassroots Mobilization and Voter Turnout in 2004. Public Opinion Quarterly 69(5):760-777.

Burden, Barry C. 2004. An Alternative Account of the 2004 Presidential Election, The Forum 2(4): Article 2. http://www.bepress.com/forum/vol2/iss4/art2.

Campbell, James E. 2005. Why Bush Won the Presidential Election of 2004: Incumbency, Ideology, Terrorism, and Turnout. Political Science Quarterly 120(2):219-241.

Citrin, Jack, Eric Schickler, and John Sides. 2003. What If Everyone Voted? Simulating the Impact of Increased Turnout in Senate Elections. American Journal of Political Science 47(1):75-90.

DeNardo, James. 1980. Turnout and the Vote: The Joke's on the Democrats. American Political Science Review 74(2):406-420.

Donovan, Todd, Caroline J. Tolbert, and Daniel A. Smith. 2005. Do State-Level Ballot Measures Affect Presidential Elections? Gay Marriage and the 2004 Election. 
Paper presented at the Annual Meetings of the American Political Science Association, Washington.

Economist. 2004. Into the Final Straight. The Economist 373(8399):31-32.

Erikson, Robert S. 1995. State Turnout and Presidential Voting. American Politics Quarterly 23(4):387-396.

Fiorina, Morris P., with Samuel J. Abrams, and Jeremy C. Pope. 2005. Culture War? The Myth of a Polarized America. New York: Pearson Longman.

Haider-Markel, Donald. 1999. Aids and Gay Civil Rights: Politics and Policy at the Ballot Box. American Review of Politics 20(Winter):349-375.

Leip, David. 2005. Dave Leip's Atlas of U.S. Presidential Elections. (Accessed June 1, 2005) http://www.uselectionatlas.org/.

Martinez, Michael D., and Jeff Gill. 2005. The Effects of Turnout on Partisan Outcomes in U.S. Presidential Elections, 1960-2000. Journal of Politics 67(4):1248-1274.

McDonald, Michael P. 2003. On the Overreport Bias of the National Election Study Turnout Rate. Political Analysis 11(2):180-186.

McDonald, Michael P. 2004. Up, Up, and Away! Voter Participation in the 2004 Presidential Election. The Forum 2(2): Article 4. http://www.bepress.com/forum/vol2 /iss4/art4.

McDonald, Michael P. and Samuel L. Popkin. 2001. The Myth of the Vanishing Voter. American Political Science Review 95(4):963-974.

Nagel, Jack H., and John E. McNulty. 1996. Partisan Effects of Voter Turnout in Senatorial and Gubernatorial Elections. American Political Science Review 90(4):780-793.

Nagel, Jack H., and John E. McNulty. 2000. Partisan Effects of Voter Turnout in Presidential Elections. American Politics Quarterly 28(3):408-429.

Radcliff, Benjamin. 1994. Turnout and the Democratic Vote. American Politics Quarterly 22(3):259-276.

Tucker, Harvey J., and Arnold Vedlitz. 1986. Controversy: Does Heavy Turnout Help Democrats in Presidential Elections? American Political Science Review 80(4): 1291-304. 
